Canadian

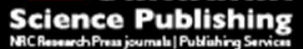

Botany

Botanique

\title{
Slow imbibition of Annona emarginata (Annonaceae) seeds: metabolic and ultrastructural evaluations
}

\begin{tabular}{|c|c|}
\hline Journal: & Botany \\
\hline Manuscript ID & cjb-2017-0110.R1 \\
\hline Manuscript Type: & Article \\
\hline Date Submitted by the Author: & 17-Aug-2017 \\
\hline Complete List of Authors: & $\begin{array}{l}\text { Gimenez, Juliana; Universidade Estadual Paulista Julio de Mesquita Filho } \\
\text { Instituto de Biociencias Campus de Botucatu, Botânica } \\
\text { Esteves-Amaro, Amanda; Universidade Estadual Paulista Julio de Mesquita } \\
\text { Filho Instituto de Biociencias Campus de Botucatu, Botânica } \\
\text { Machado, Silvia; Universidade Estadual Paulista Julio de Mesquita Filho } \\
\text { Instituto de Biociencias Campus de Botucatu, Botânica } \\
\text { Ferreira, Gisela; Universidade Estadual Paulista Julio de Mesquita Filho } \\
\text { Instituto de Biociencias Campus de Botucatu, Botânica }\end{array}$ \\
\hline $\begin{array}{r}\text { Is the invited manuscript for } \\
\text { consideration in a Special } \\
\text { Issue? : }\end{array}$ & N/A \\
\hline Keyword: & $\begin{array}{l}\text { Annonaceae, Antioxidant system, Membrane damage, Mitochondria, } \\
\text { Ultrastructure }\end{array}$ \\
\hline
\end{tabular}


Title: Slow imbibition of Annona emarginata (Annonaceae) seeds: metabolic and ultrastructural evaluations

Juliana Iassia Gimenez ${ }^{1 *}$, Amanda Cristina Esteves Amaro ${ }^{1}$, Silvia Rodrigues Machado ${ }^{1}$, Gisela Ferreira ${ }^{1}$

${ }^{1}$ UNESP - Univ. Estadual Paulista, Instituto de Biociências, Departamento de Botânica, Campus de Botucatu, P.O. Box 510, Botucatu 18618-689, SP, Brazil.

*Corresponding author: julianaiassia@gmail.com , Phone +55 143880 0124, Fax +55 143815 3744 . 


\begin{abstract}
The germination pattern may be affected when seeds are dispersed in flooding conditions or subjected to pre-germination treatments, such as immersion in plant growth regulators and priming. We evaluated metabolic and ultrastructural changes in Annona emarginata seeds caused by immersion in water $(0 \mathrm{MPa})$ during the imbibition phase (phase I). The immersion time necessary for initially dry seeds $(10 \%$ water content) to reach $15 \%, 20 \%$ and $35 \%$ water contents was recorded. The seeds were also immersed in a polyethylene glycol 6000 solution (1.2 $\mathrm{MPa}$ ) to decrease the rate of water uptake and increase the immersion times required for the seeds to reach the selected water contents. With shorter immersion times, seed damage did not decrease germinability. Seeds immersed for 122 hours sustained damage to the cell membrane system and organelles, resulting in a decreased germination percentage and rate. Decreasing the rate of water uptake increased the time required to finish imbibition phase to 317 hours and resulted in more ultrastructural damages and a decreased germination index. We conclude that in seeds with slower imbibition, longer immersion times may cause severe metabolic damage if the seeds are immersed until the end of the imbibition phase, resulting in a lower germination.
\end{abstract}

Key words: Annonaceae, Antioxidant system, Membrane damage, Mitochondria, Ultrastructure. 


\section{Introduction}

Water uptake during seed germination is triphasic, and imbibition is the first phase (phase I). It is usually rapid and involves the uptake of large volumes of water driven by differences in water potential between dry orthodox seeds and the medium (Weitbrecht et al. 2011). Although considered to be fast, the duration of imbibition can vary because of several factors, such as the composition of the seed coat and seed reserves, humidity and ambient temperature, and water temperature (Soriano et al. 2011).

Because imbibition is a physical process that is driven by differences in matric potential $\left(\Psi_{\mathrm{m}}\right)$, it also occurs in dead seeds (Krishnan et al. 2004). However, it should be noted that during this phase, i.e., the beginning of rehydration, the metabolism of alive orthodox seeds, which was decreased before dispersal, is reactivated (Weitbrecht et al. 2011), increasing respiration and initiating the germination process (Benamar et al. 2008). Imbibition is of great importance for the germination process because seed metabolism is reactivated during this phase. For this reason, the duration of imbibition has been used to determine the duration of pregermination treatments, such as immersion in plant growth regulators (Amaro et al. 2009; Oliveira et al. 2010) and priming (Sharma et al. 2014).

However, the high rate of water entry into the seed that takes place during imbibition can damage the seed. Imbibition is therefore also a critical phase, during which irreversible damage to cell membranes may occur, as membranes change from a gel to a liquid crystalline state (Corbineau 2012). This damage results in the electrolyte leakage, as sugars and amino acids leach from the cell, compromising germination (Kokubun 2013). Decreasing the rate of water entry into seeds by changing the osmotic potential $\left(\Psi_{\mathrm{s}}\right)$ of the immersion solution has been used as a strategy to avoid this damage (Chen et al. 2013; Paparella et al. 2015). Slower seed hydration allows more time for cell membrane repair and/or reorganization, reducing the risk of damage to the embryo (Varier et al. 2010; Sharma et al. 2014). 
However, similar to what is observed during long periods of flooding, we hypothesized that long periods of immersion, caused by the reduction in water acquisition speed, may result in seed stress due to low oxygen availability (hypoxia) in the medium under these conditions. Hypoxia results in the production of reactive oxygen species (ROS), such as the superoxide anion radical $\left(\mathrm{O}_{2}^{-}\right)$, hydrogen peroxide $\left(\mathrm{H}_{2} \mathrm{O}_{2}\right)$, and the hydroxyl radical $\left(\mathrm{OH}^{-}\right)$(Jaleel et al. 2007). ROS may react with several biological molecules, such as DNA, RNA, carbohydrates, proteins (Job et al. 2005), and lipids (Garg and Manchanda 2009), and are detrimental to cell function. For example, ROS can react with lipids and induce lipid peroxidation, resulting in changes in membrane permeability, membrane degradation, or cell death (Greggains et al. 2000; Ratajczak and Pukacka 2005). Oxidative damage of mitochondrial proteins may cause the disintegration of the mitochondrial matrix (Bartoli et al. 2004) and changes to mitochondrial membranes, affecting mitochondrial activity and resulting in decreased energy production (Yin et al. 2009). Plants control ROS by an antioxidant defense system that efficiently maintains ROS at non-toxic levels and includes the enzymes superoxide dismutase (SOD), catalase (CAT) and peroxidase (POD) (Foyer and Noctor 2005).

The aim of this study was to investigate whether increasing the time required to reach the level of the imbibition curve plateau (lag phase) by decreasing the rate of water uptake results in a decrease in germination and if this is associated with ultrastructural and metabolic damage of Annona emarginata (Schltdl.) H. Rainer seeds.

\section{Material and methods}

Seed Immersion

The Annona emarginata fruits were collected from matrix plants destined for the production of certified seedlings, belonging to the Secretary of Agriculture of the Government of the State of São Paulo, Brazil. Seeds with $10 \%$ initial water concentration were subjected to imbibition at $25^{\circ} \mathrm{C} \pm 2{ }^{\circ} \mathrm{C}$ by seed immersion in water or a polyethylene glycol 6000 solution 
with a water potential of $-1.2 \mathrm{MPa}$ (Villela et al. 1991) to decrease the rate of water uptake. Imbibition was stopped when the seeds reached $15 \%, 20 \%$ and $35 \%$ water content, monitored by gravimetric method in a control sample.

\section{Dissolved Oxygen Concentrations in Immersion Solutions}

The dissolved oxygen concentrations in the immersion solutions were measured according to an electrometric method using an oximeter PHTEK DO-48 (Kayto Eletronics Inc., China). The results were expressed in milligrams of oxygen per liter of immersion solution (mg $\left.\mathrm{L}^{-1}\right)$.

Electrolyte leakage

Electrolyte leakage was determined at the end of the different seed immersion times by measuring the bulk electrical conductivity of the immersion solutions. The results are expressed in microSiemens per centimeter $\left(\mu \mathrm{S} \mathrm{cm}^{-1}\right)$.

\section{Transmission Electron Microscopy}

Analyses of seed ultrastructure were performed using transmission electron microscopy (TEM). The embryo axes and cotyledons were collected from seeds after each imbibition period $(0 \mathrm{~h}, 122 \mathrm{~h}$ and $317 \mathrm{~h})$ and were immediately fixed with $2.5 \%$ glutaraldehyde (in $0.1 \mathrm{M}$ phosphate buffer, $\mathrm{pH} 7.3)$, at $4{ }^{\circ} \mathrm{C}$ overnight, and post-fixed with $1 \%$ osmium tetroxide $\left(\mathrm{OsO}_{4}\right)$ (in $0.1 \mathrm{M}$ phosphate buffer) for 2 hours at room temperature. The samples were dehydrated in a graded acetone series and embedded in araldite resin. Ultra-thin sections were stained with uranyl acetate and lead citrate (Reynolds 1963) and were observed using a Philips 100 TEM microscope (Philips, Czech Republic) operating at $60 \mathrm{kV}$.

\section{Determination of Malondialdehyde (Lipid Peroxidation)}


The seed malondialdehyde concentrations were determined at the end of each immersion time according to Heath and Packer (1968), in four replications with 32 seeds. The malondialdehyde concentrations were calculated using the extinction coefficient of malondialdehyde $\left(155 \mathrm{mmol} \mathrm{L}^{-1} \mathrm{~cm}^{-1}\right)$, and the results are expressed in nanomol of malondialdehyde per gram dry weight (nmol malondialdehyde $\mathrm{g}^{-1} \mathrm{DW}$ ).

Determination of Antioxidant Enzyme Activity: Superoxide Dismutase, Catalase and Peroxidase

Enzyme extraction was performed according to Kar and Mishra (1976), in four replications with 32 seeds. Superoxide dismutase (SOD) (EC 1.15.1.1) activity was determined according to Peixoto et al. (1999). Specifically, SOD activity was determined by measuring its ability to inhibit the photoreduction of nitroblue tetrazolium (NBT). Absorbance was measured at $560 \mathrm{~nm}$ using a spectrophotometer. SOD activity is expressed in unit per milligram protein (U $\mathrm{mg}^{-1}$ protein). One unit of SOD is defined as the amount of enzyme capable of inhibiting $50 \%$ NBT photoreduction under the assayed conditions. Catalase (EC 1.11.1.6) activity was determined according to Peixoto et al. (1999). Absorbance was measured at $240 \mathrm{~nm}$ using a spectrophotometer, and enzyme activity was calculated using the $\mathrm{H}_{2} \mathrm{O}_{2}$ molar extinction coefficient $\left(39.4 \mathrm{mmol} \mathrm{L}^{-1} \mathrm{~cm}^{-1}\right)$. Catalase activity is expressed in nanomol $\mathrm{H}_{2} \mathrm{O}_{2}$ consumed per minute per milligram protein (nmol $\mathrm{H}_{2} \mathrm{O}_{2}$ consumed $\min ^{-1} \mathrm{mg}^{-1}$ protein). Peroxidase (EC 1.11.1.7) activity was determined according to Teisseire and Guy (2000). The formation of purpurogallin was measured at $430 \mathrm{~nm}$ using a spectrophotometer. Peroxidase specific activity was calculated using the purpurogallin molar extinction coefficient $\left(2.5 \mathrm{mmol} \mathrm{L}^{-1} \mathrm{~cm}^{-1}\right)$ and is expressed in micromol purpurogallin per minute per milligram protein $\left(\mu \mathrm{mol}\right.$ purpurogallin $\min ^{-}$ ${ }^{1} \mathrm{mg}^{-1}$ protein).

Germination Tests 
Seed germination tests were performed on the seeds subjected to the different water contents. When the seeds reached each of the water levels, five replications with 50 seeds were collected and were placed on filter paper for germination moistened with deionized water and kept in a germinator under an $8 \mathrm{~h}$ dark $/ 16 \mathrm{~h}$ light photoperiod at $20^{\circ} \mathrm{C} / 30^{\circ} \mathrm{C}($ Costa et al. 2011). Germinated seeds, defined by the appearance of a radicle at least $2 \mathrm{~mm}$ long, were counted every 2 days. Germination percentage, speed of germination index (Silva and Nakagawa, 1995) and average germination time (Edmond and Drapala 1958) were quantified.

\section{Data analysis}

The data were subjected to analysis of variance ( $F$ test) followed by Tukey's test at $p<0.05$.

\section{Results}

The seeds immersed in pure water ( $\left.\Psi_{\mathrm{w}} 0 \mathrm{MPa}\right)$ reached $15 \%$ water content after 4 hours of immersion, $20 \%$ water content after 9 hours, and $35 \%$ water content (end of imbibition, lag or plateau phase) after 122 hours. Decreasing the rate of water uptake by immersing the seeds in a solution with a $\Psi_{\mathrm{W}}$ of $-1.2 \mathrm{MPa}$ increased the time needed for the seeds to reach $15 \%, 20 \%$ and $35 \%$ water content to 6,16 and 317 hours, respectively. The dissolved oxygen concentrations decreased over time as the seed water contents increased, for both immersion solutions tested (0 and $-1.2 \mathrm{MPa})$ (Table 1). The dissolved oxygen concentrations were lower for the -1.2 MPa immersion solution, independent of the seed water contents. In these conditions, metabolic and structural changes take place from the start of imbibition, resulting in reduced germination when the imbibition time is extended causing irreparable damage.

The occurrence of seed damage caused by the duration of seed immersion was investigated through quantification of the leachate (Table 2), oxidative system and lipid 
peroxidation (Table 3). In seeds with $20 \%$ water content, decreased germination resulting from damage caused by water entry was only observed at the lower rate of water uptake. Thus, after 9 hours of immersion in water $(0 \mathrm{MPa})$ there was an increase in the leachate (Table 2$)$ that was accompanied by increased malondialdehyde (MDA) concentrations (Table 3). However, increased SOD activity was observed in these seeds (Table 3), which reduced the damage and maintained the germination percentage (Table 4). At the lower rate of water uptake (-1.2 MPa), both the leachate (Table 2) and MDA concentrations (Table 3) remained constant. However, electrolyte leakage in these seeds was higher than that in the seeds immersed in water (0 MPa) from the beginning of imbibition (15\% water content).

At the end of imbibition (35\% water content), metabolic damage and ultrastructural seed damage were observed with both natural (shorter time: 122 hours) and decreased rates of water uptake (longer time: 317 hours). However, the damage was more severe in the seeds at the lower rate of water uptake (-1.2 MPa), resulting in lower germination percentages (15\%) than the seeds immersed in water (0 MPa) (42\%) (Table 4).

The leachate values increased $\left(0.165 \mu \mathrm{S} \mathrm{cm}^{-1}\right)$ after imbibition for 122 hours $(35 \%$ water content). When the seeds reached $35 \%$ water content at a slower pace, i.e., after 317 hours, we observed higher leachate values $\left(0.264 \mu \mathrm{S} \mathrm{cm}^{-1}\right)$ compared with imbibition for 122 hours (Table 2). The seeds with the slower imbibition (317 hours) also presented the highest MDA concentrations (10.5 $\mathrm{nmol} \mathrm{g}^{-1} \mathrm{DW}$; Table 3), indicating more severe damage of the cell membrane. In these seeds, the SOD activity was low, and only the POD activity increased. This was not sufficient to control the ROS levels and resulted in higher lipid peroxidation. No changes in the CAT activity were observed for any of the tested imbibition conditions. Therefore, increasing the time of immersion until the seeds reached $35 \%$ water content caused more extensive damage to the cell membranes due to increased lipid peroxidation and high electrolyte leakage. 
As metabolic indications of more extensive damage were observed in the seeds immersed until the end of imbibition (122 hours at $0 \mathrm{MPa}$ and 317 hours at $-1.2 \mathrm{MPa}$ ), we used transmission electron microscopy (TEM) to visualize the cellular changes (Figure 1).

In the seeds with $10 \%$ water content (before imbibition) the parenchyma cells of radicle exhibited uniformly thick cell walls, plasma membrane, prominent nucleus, mitochondria with distinguishable internal and external membranes, endoplasmic reticulum, numerous small lipid droplets, starch grains, and storage vacuoles containing polysaccharides, seen as very small electron dense granulations (Figure $1 \mathrm{~A}-\mathrm{C}$ ). Changes were observed in the embryo parenchyma cells of the seeds with $35 \%$ water content (immersed for 122 or 317 hours) (Figure 1 D-I). The seeds immersed for 122 hours presented more abundant mitochondria, with an irregular shape, poorly developed cristae, and limited distinction between the internal and external membranes (Figure $1 \mathrm{E}, \mathrm{F}$ ). In addition to these changes, the seeds immersed for 317 hours also presented non-uniform cell walls with signs of degradation and disruption of sugar-containing storage vacuoles (Figure $1 \mathrm{G}-\mathrm{I}$ ). These sugars had leached into the immersion solution, resulting in the higher electrolyte leakage values observed (Table 2).

The ultrastructural and metabolic damage observed in the seeds immersed until the end of imbibition (35\%), at both rates of water uptake tested (immersion solution with $0 \mathrm{MPa}$ or 1.2 MPa), negatively affected germination (Table 4), resulting in a lower germination percentage and speed of germination index (SGI), and a higher average germination time (AGT). For the seeds immersed in water $(0 \mathrm{MPa})$, the germination percentage decreased from $67 \%$ (for seeds with $10 \%$ water content) to $42 \%$ (35\% water content), the SGI decreased from 1.54 to 0.74 , and the AGT increased from 24 to 30 days. These changes were even more pronounced for the seeds with a lower rate of water uptake and a higher immersion time (317 hours), which had $15 \%$ germination, an SGI of 0.17 , and an AGT of 45 days. Several cellular and metabolic events therefore indicated that seed damage negatively affected germination. 


\section{Discussion}

The present study confirms the importance of generating a seed imbibition curve to determine the duration of treatments involving seed immersion in aqueous solutions (Braga et al. 2010; Gimenez et al. 2014a; b). It is also important to understand the metabolic processes occurring at different seed water contents until the end of imbibition to avoid wrongfully interpreting the results.

The first increase in seed respiration and, therefore, in mitochondrial activity usually occurs when seeds reach $20 \%$ water content (Patanè et al. 2006). The mitochondrial respiratory chain is the major source of ROS in cells (Rhoads et al. 2006). The ROS increase due to higher respiration, resulting in increased membrane damage as indicated by higher concentrations of MDA, which is a by-product of membrane lipid peroxidation (Liu et al. 2009). This increase in lipid peroxidation coincided with an increase in electrolyte leakage, confirming membrane damage. Higher SOD activity was also observed in these seeds, which effectively lowered ROS to non-toxic (less toxic) levels, avoiding even greater damage.

In contrast, decreasing the rate of water uptake to reach $20 \%$ water content may have resulted in lower oxygen availability in the imbibition solution, which may have prevented increases in respiration. This resulted in lower ROS production and lipid peroxidation. However, if respiration did not increase, seed metabolism may have remained unchanged, which would explain the decrease in germination percentage. Although lipid peroxidation was lower, which would suggest lower membrane damage, electrolyte leakage was higher. The present results therefore show that decreasing the rate of water entry into the seed does not always prevent the occurrence of irreparable damages caused to the membrane system, and consequently, germination is not guaranteed.

Damage caused to the cell membranes of the seeds immersed for 122 hours ( $0 \mathrm{MPa} ; 35$ $\%$ water content) resulted in higher electrolyte leakage from the cells into the medium and decreased the germination percentage. Similar results have been observed in previous studies 
(Weitbrecht et al. 2011; Ocvirk et al. 2014). In the seeds immersed for 317 hours, the decrease in the rate of water uptake and resulting increased time of immersion required to reach $35 \%$ water content further affected membrane integrity, as indicated by the higher electrolyte leakage $\left(0.264 \mu \mathrm{S} \mathrm{cm}^{-1} \mathrm{~g}^{-1}\right.$, increase of $60 \%$ in relation to the control). Higher electrolyte leakage may also be related to seed deterioration (Corbineau 2012), which could have resulted from the long immersion time in the solution with low oxygen availability. In addition, analysis of the cell ultrastructure showed the breaking of the membranes of the sugar-containing storage vacuoles, which coincided with the increased electrolyte leakage. The decrease in the amount of sugars available as an energy source for the maintenance of embryo metabolism and growth therefore resulted in the lowest germination percentages observed (15\%).

The seeds immersed for 122 hours (faster imbibition, $0 \mathrm{MPa}, 35 \%$ water content) presented lower lipid peroxidation because of higher SOD and POD activities. These two enzymes effectively controlled the ROS levels but were not able to prevent increases in the leachate. In contrast, lipid peroxidation may have increased in the seeds immersed for 317 hours (slower imbibition, -1.2 MPa, $35 \%$ water content) because of the increase in ROS caused by changes in mitochondrial membranes (Yin et al. 2009). In these seeds, the antioxidant defense system did not appear to be sufficient to control the ROS level because only the POD activity increased; the SOD and CAT presented low activities. Thus, as mitochondria are a potential source of $\mathrm{O}_{2}{ }^{-}$and its elimination is performed by SOD (Mittler 2002), the ROS levels remained high, resulting in higher lipid peroxidation.

The damage caused by the long seed immersion times was visualized through the analysis of the embryo cell ultrastructure. Cellular damage that results in modifications to the mitochondrial structure, such as decreased or absent cristae and membrane disorganization, may affect oxidative phosphorylation, during which ATP is produced (Frey and Mannella 2000). Similar mitochondrial damage has been observed in seeds of Glycine $\max$ L. subjected to imbibition at low temperatures (Yin et al. 2009). The authors noted that because the embryo 
does not possess chloroplasts for photophosphorylation and mitochondria are the main energy source during imbibition, this damage resulted in low ATP availability.

Furthermore, similar to flooding, immersion for long periods of time subjected the seeds to hypoxia, even with the use of artificial aeration. Therefore, in addition to the mitochondrial damage, the oxygen availability was also lower. This compromised ATP production because oxygen is the final electron acceptor in oxidative phosphorylation (Gupta et al. 2009). The cumulative effect of these factors could decrease ATP production to levels lower than the cell demand, compromising the seed metabolism. The maintenance of seed metabolism and survival under hypoxic conditions is directly related to the capacity to produce energy under these conditions (Shingaki-Wells et al. 2014). We can therefore conclude that in addition to electrolyte leakage and inefficiency of the antioxidative system, decreased energy production because of mitochondrial damage and hypoxia resulted in decreased germination of the $A$. emarginata seeds.

We therefore highlight that the maximum immersion time that does not cause seed damage needs to be determined for each species. For species that take up water slowly, such as A. emarginata, seed immersion until the end of the imbibition phase (phase I) mostly damages mitochondria and cell membranes. If the rate of water uptake is decreased, increasing the imbibition time, the damage increases further. However, for seeds with a faster rate of water uptake and a shorter imbibition phase, such as A. squamosa (5 hours) (Ferreira et al. 2002) and A. cherimola x A. squamosa (36 hours) (Braga et al. 2010; Oliveira et al. 2010), immersion until the end of imbibition is not detrimental and results in high germinability. In summary, the knowledge that slow imbibition up to the lag phase of the seed imbibition curve causes ultrastructural damage and changes to the metabolism of $A$. emarginata seeds, even with the use of an artificial aeration system, explains the low germination percentages of some plant species when seeds are subjected to long periods of immersion, especially species with slow imbibition. 
Funding: This work was supported by São Paulo Research Foundation (Fundação de Amparo à Pesquisa do Estado de São Paulo - FAPESP) [grant number 2012/24013-1].

\section{References}

Amaro, A.C.E., Zucareli, V., Mischan, M.M., and Ferreira, G. 2009. Combinações entre GA $_{4+7}$ + N-(fenilmetil)-aminopurina e ethephon na germinação de sementes de Passiflora cincinnata Mast. Rev. Bras. Sementes, 31: 195-202.

Bartoli, C.G., Gómez, F., Martínez, D.E., and Guiamet, J.J. 2004. Mitochondria are the main target for oxidative damage in leaves of wheat (Triticum aestivum L.). J. Exp. Bot. 55 (403): 1663-1669. doi:10.1093/jxb/erh199.

Benamar, A., Rolletschek, H., Borisjuk, L., Avelange-Macherel, M.H., Curien, G., Mostefai, H.A., Andriantsitohaina, R., and Macherel, D. 2008. Nitrite-nitric oxide control of mitochondrial respiration at the frontier anoxia. Biochim. Biophys. Acta, 1777: 1268-1275. doi:10.1016/j.bbabio.2008.06.002.

Braga, J.F., Ferreira, G., Pinho, S.Z., Braga, L.F., and Sousa, M.P. 2010. Germination of atemoya (Annona cherimola Mill. x A. squamosa L.) cv. Gefner seeds subjected to treatments with plant growth regulators. International Journal of Science and Nature, 1 (2): 120-126.

Chen, K., Fessehaie, A., and Arora, R., 2013. Aquaporin expression during seed osmopriming and post-priming germination in spinach. Biol. Plantarum, 57: 193-198.

Corbineau, F., 2012. Markers of seed quality: from present to future. Seed Sci Res 22: S61-S68.

Costa, P.N., Bueno, S.S.C., and Ferreira, G. 2011. Fases da germinação de sementes de Annona emarginata (Schltdl.) H. Rainer em diferentes temperaturas. Rev. Bras. Fruticultura, 33: 253260.

Edmond, J.B., and Drapala, W.S. 1958. The effects of temperature, sand and acerone on germination of okra seed. Proc. Am. Soc. Horticult. Sci. 71: 428-434. 
Ferreira, G., Erig, P.R., and Moro, E. 2002. Uso de ácido giberélico em sementes de fruta-doconde (Annona squamosa L.) visando a produção de mudas em diferentes embalagens. Rev. Bras. Fruticultura, 24: 178-182.

Foyer, C.H., and Noctor, G., 2005. Redox homeostasis and antioxidant signaling: a metabolic interface between stress perception and physiological responses. Plant Cell, 17: 1866-1875.

Frey, T.G., and Mannella, C.A. 2000. The internal structure of mitochondria. Trends Biochem. Science, 25: 319-324.

Garg, N., and Manchanda, G. 2009. ROS generation in plants: boon or bane? Plant Biosystems, 143: 81-96.

Gimenez, J.I., Ferreira, G., and Corsato, J.M. 2014a. Soluble sugars and germination of Annona emarginata (Schltdl.) H. Rainer seeds submitted to immersion in $\mathrm{GA}_{3}$ up to different water contents. Rev. Bras. Fruticultura, 36: 281-287.

Gimenez, J.I., Ferreira, G., and Cavariani, C. 2014b. Tetrazolium test for assessment of seed viability of atemoya (Annona cherimola Mill. x A. squamosa L.). J. Seed Sci. 36 (3): 357-361. doi:10.1590/2317-154v36n31004.

Greggains, V., Finch-Savage, W.E., Quick, W.P., and Atherton, N.M. 2000. Metabolisminduced free radical activity does not contribute significantly to loss of vialibility in moiststored recalcitrant seeds of contrasting species. New Phytol. 148: 267-276.

Gupta, K.J., Zabalza, A., and van Dongen, J.T. 2009. Regulation of respiration when the oxygen availability changes. Physiol. Plantarum, 137: 383-391. doi:10.1111/j.1399-3054.2009.01253.x.

Heath, R.L., and Packer, L. 1968. Photoperoxidation in isolated chloroplasts I. Kinetics and stoichiometry of fatty acid peroxidation. Arch. Biochem. Biophys. 125: 189-198.

Jaleel, C.A., Manivannan, P., Sankar, B., Kishorekumar, A., Gopi, R., Somasundaram, R., and Panneerselvam, R. 2007. Water deficit stress mitigation by calcium chloride in Catharanthus roseus: effects on oxidative stress, proline metabolism and indole alkaloid accumulation. Colloids Surf. B: Biointerfaces, 60: 110-116. doi: 10.1016/j.colsurfb.2007.06.006. 
Job, C., Rajjou, L., Lovigny, Y., Belghazi, M., and Job, D. 2005. Patterns of protein oxidation in Arabidopsis seeds and during germination. Plant Physiol. 138: 790-802. doi:10.1104/pp.105.062778.

Kar, M., and Mishra, D. 1976. Catalase, Peroxidase, and Polyphenoloxidase Activities during Rice Leaf Senescence. Plant Physiol. 57: 315-319.

Kokubun, M. 2013. Genetic and cultural improvement of soybean for waterlogged conditions in Asia. Field Crop Res. 152: 3-7. doi:10.1016/j.fcr.2012.09.022.

Krishnan, P.; Joshi, D.K.; Nagarajan, S., and Moharir, A.V. 2004. Characterization of germinating and non-viable soybean seeds by nuclear magnetic resonance (NMR) spectroscopy. Seed Sci. Res. 14 (4): 355-362. doi:10.1079/SSR2004189.

Liu, Z.J., Zhang, X.L., Bai, J.G., Suo, B.X., Xu, P.L., and Wang, L. 2009. Exogenous paraquat changes antioxidant enzyme activities and lipid peroxidation in drought-stressed cucumber leaves. Sci. Hortic. 121 (2): 138-143. doi:10.1016/j.scienta.2009.01.032.

Mittler, R. 2002. Oxidative stress, antioxidants and stress tolerance. Trends Plant Sci. 7 (9): 405-410.

Ocvirk, D., Spoljarevic, M., Markovic, S.S., Lisjak, M., Hanzer, R., and Teklic, T. 2014. Seed germinability after imbibition in electrical conductivity test and relations among maize seed vigour parameters. J. Food Agric. Environ. 12: 140-145.

Oliveira, M.C., Ferreira, G., Guimarães, V.F., and Dias, G.B. 2010. Germinação de sementes de atemoia (Annona cherimola Mill. x A. squamosa L.) cv 'Gefner' submetidas a tratamentos com ácido giberélico $\left(\mathrm{GA}_{3}\right)$ e ethephon. Rev. Bras. Fruticultura, 32: 544-554.

Paparella, S.; Araújo, S.S.; Rossi, G.; Wijayasinghe, M.; Carbonera, D., and Balestrazzi, A. 2015. Seed priming: state of the art and new perspectives. Plant Cell Rep. 34: 1281-1293. doi:10.1007/s00299-015-1784-y. 
Patanè, C.; Cavallaro, V.; Avola, G., and D’Agosta, G. 2006. Seed respiration of sorghum [Sorghum bicolor (L.) Moench] during germination as affected by temperature and osmoconditioning. Seed Sci. Res. 16: 251-260. doi:10.1017/SSR2006259.

Peixoto, H.P.P., Cambraia, J., Sant'Ana, R., Mosquim, P.R., and Moreira, A.M. 1999. Aluminium effects on lipid peroxidation and the activities of enzymes of oxidative metabolism in sorghum. Rev. Bras. Fisiol. Veg. 11: 137-143.

Ratajczak, E., and Pukacka, S. 2005. Decrease in beech (Fagus sylvatica) seed viability caused by temperature and humidity conditions as related to membrane damage and lipid composition. Acta Physiol. Plant. 27 (1): 3-12.

Reynolds, E.S. 1963. The use of lead citrate at high $\mathrm{pH}$ as an electron-opaque stain in electron microscopy. J. Cell Biol. 17: 208-212.

Rhoads, D.M., Umbach, A.L., Subbaiah, C.C., and Siedow, J.N. 2006. Mitochondrial reactive oxygen species. Contribution to oxidative stress and interorganellar signaling. Plant Physiol. 141 (2): 357-366. doi:10.1104/pp.106.079129.

Sharma, A.D., Rathore, S.V.S., Srinivasan, K., and Tyagi, R.K. 2014. Comparison of various seed priming methods for seed germination, seedling vigour and fruit yield in okra (Abelmoschus esculentus L. Moench.). Sci. Hortic. 165: 75-81. doi:10.1155/2012/217037.

Shingaki-Wells, R.; Millar, A.H.; Whelan, J., and Narsai, R. 2014. What happens to plant mitochondria under low oxygen? An omics review of the responses to low oxygen and reoxygenation. Plant Cell Environ. 37: 2260-2277. doi:10.1111/pce.12312.

Silva, J.B., and Nakagawa, J. 1995. Estudos de fórmulas para cálculo de velocidade de germinação. Informativo Abrates, 5: 62-73.

Soriano, D., Orozco-Segovia, A., Márquez-Guzmán, J., Kitajima, K., Buen, A.G., and Huante, P. 2011. Seed reserve composition in 19 tree species of a tropical deciduous forest in Mexico and its relationship to seed germination and seedling growth. Ann. Bot. 107: 939-951. doi:10.1093/aob/mcr041. 
Teisseire, H., and Guy, V. 2000. Copper-induced changes in antioxidant enzymes activities in fronds of duckweed (Lemna minor). Plant Sci. 153 (1): 65-72. doi:10.1016/S01689452(99)00257-5.

Varier, A., Vari, A.K., and Dadlani, M. 2010. The subcellular basis of seed priming. Curr. Sci. 99 (4): $450-456$.

Villela, F.A., Doni Filho, L., and Sequeira, E.L. 1991. Tabela de potencial osmótico em função da concentração de polietilenoglicol 6000 e da temperatura. Pesquisa Agropecuária Brasileira, $26(11 / 12):$ 1957-1968.

Weitbrecht, K., Müller, K., and Leubner-Metzger, G. 2011. First on the mark: early seed germination. J. Exp. Bot. 62 (10): 3289-3309. doi:10.1093/jxb/err030.

Yin, G., Sun, H., Xin, X., Qin, G., Liang, Z., and Jing, X. 2009. Mitochondrial damage in the soybean seed axis during imbibition at chilling temperatures. Plant Cell Physiol. 50 (7): 13051318. doi:10.1093/pcp/pcp074. 


\section{Tables}

Table 1. Dissolved oxygen (mg L $\left.{ }^{-1}\right)$ in the immersion solutions of $A$. emarginata (Schltdl.) H. Rainer seeds when different water contents were reached.

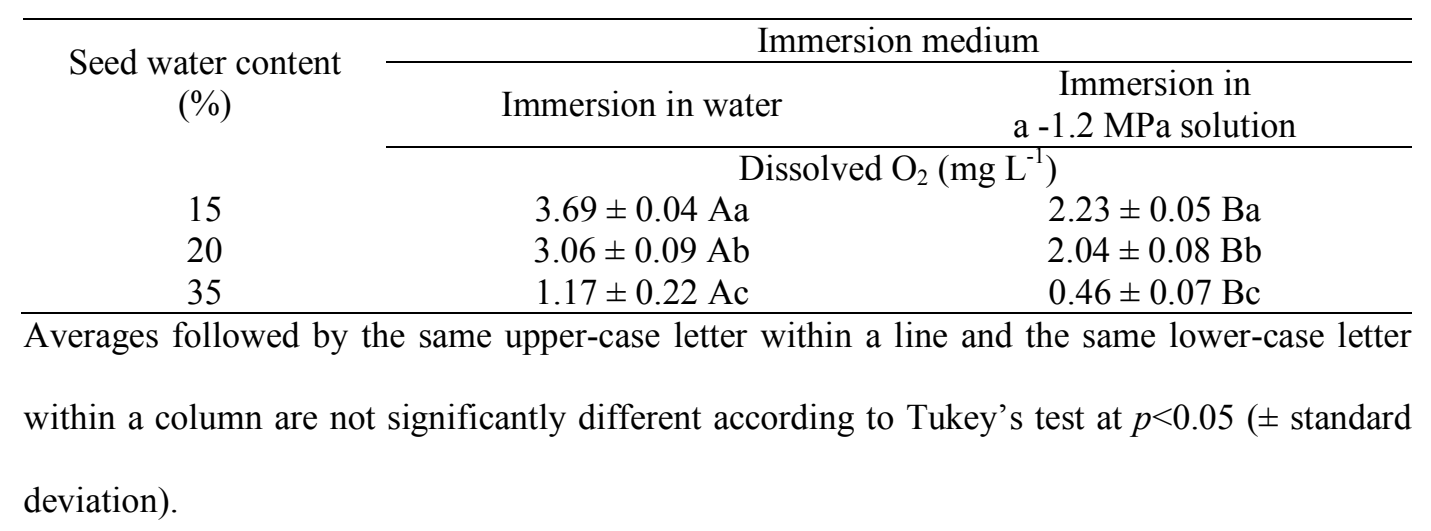


Table 2. Electrical conductivity (E.C. $\left[\mu \mathrm{S} \mathrm{cm}^{-1} \mathrm{~g}^{-1}\right]$ ) of immersion solutions, water or a -1.2 MPa, of A. emarginata (Schltdl.) H. Rainer seeds when different water contents were reached.

\begin{tabular}{ccc}
\hline Seed water content & \multicolumn{2}{c}{ E.C. $\left(\mu \mathrm{Sm}^{-1} \mathrm{~g}^{-1}\right)$} \\
\cline { 2 - 3 }$(\%)$ & Immersion in water & Immersion in a $-1.2 \mathrm{MPa}$ solution \\
\hline 10 (initial) & $0.007 \pm 0.001 \mathrm{Ad}$ & $0.007 \pm 0.001 \mathrm{Ac}$ \\
15 & $0.047 \pm 0.001 \mathrm{Bc}$ & $0.090 \pm 0.001 \mathrm{Ab}$ \\
20 & $0.072 \pm 0.001 \mathrm{Bb}$ & $0.091 \pm 0.001 \mathrm{Ab}$ \\
35 & $0.165 \pm 0.001 \mathrm{Ba}$ & $0.264 \pm 0.001 \mathrm{Aa}$ \\
\hline
\end{tabular}

Averages followed by the same upper-case letter within a line and the same lower-case letter within a column are not significantly different according to Tukey's test at $p<0.05$ ( \pm standard deviation). 
Table 3. Malondialdehyde concentration $\left(\mathrm{nmol} \mathrm{g}{ }^{-1} \mathrm{MS}\right)$ and superoxide dismutase $\left(\mathrm{U} \mathrm{mg}^{-1}\right.$ protein) and peroxidase ( $\mu \mathrm{mol}$ purpurogallin $\mathrm{min}^{-1} \mathrm{mg}^{-1}$ protein) activity in A. emarginata (Schltdl.) H. Rainer seeds after imbibition by immersion in water or a -1.2 MPa solution until different seed water contents were reached.

\begin{tabular}{|c|c|c|}
\hline \multirow[b]{2}{*}{ Seed water content $(\%)$} & \multicolumn{2}{|c|}{ Immersion medium } \\
\hline & Water & -1.2 MPa Solution \\
\hline & \multicolumn{2}{|c|}{ Malondialdehyde (nmol g $\left.{ }^{-1} \mathrm{DW}\right)$} \\
\hline 15 & $9.5 \pm 0.8 \mathrm{Ab}$ & $9.4 \pm 0.3 \mathrm{Aab}$ \\
\hline 20 & $11.7 \pm 0.8 \mathrm{Aa}$ & $8.7 \pm 0.2 \mathrm{Bb}$ \\
\hline 35 & $7.4 \pm 0.2 \mathrm{Bc}$ & $10.5 \pm 1.0 \mathrm{Aa}$ \\
\hline \multirow[t]{2}{*}{ C.V. $(\%)$} & \multicolumn{2}{|c|}{6.82} \\
\hline & \multicolumn{2}{|c|}{$\mathrm{SOD}\left(\mathrm{U} \mathrm{mg}^{-1}\right.$ protein $)$} \\
\hline 15 & $472.9 \mathrm{Bc} \pm 11.8 \mathrm{Bc}$ & $600.7 \pm 41.6 \mathrm{Aa}$ \\
\hline 20 & $540.6 \mathrm{Ab} \pm 1.6 \mathrm{Ab}$ & $387.9 \pm 22.5 \mathrm{Bb}$ \\
\hline 35 & $671.5 \mathrm{Aa} \pm 28.2 \mathrm{Aa}$ & $424.3 \pm 15.5 \mathrm{Bb}$ \\
\hline \multirow[t]{2}{*}{ C.V. (\%) } & 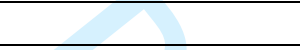 & \\
\hline & \multicolumn{2}{|c|}{ POD ( $\mu$ mol purpurogallin $\min ^{-1} \mathrm{mg}^{-1}$ protein) } \\
\hline 15 & $6.4 \pm 0.3 \mathrm{Bb}$ & $10.1 \pm 0.1 \mathrm{Ab}$ \\
\hline 20 & $6.8 \pm 0.8 \mathrm{Bb}$ & $8.3 \pm 0.8 \mathrm{Ac}$ \\
\hline 35 & $8.3 \pm 0.1 \mathrm{Ba}$ & $13.0 \pm 0.9 \mathrm{Aa}$ \\
\hline
\end{tabular}

Averages followed by the same upper-case letter within a line and the same lower-case letter within a column are not significantly different according to Tukey's test at $p<0.05$ ( \pm standard deviation). 
Table 4. Germination percentage (\%), speed of germination index (SGI) and average germination time (AGT; days) of A. emarginata (Schltdl.) H. Rainer seeds following imbibition by immersion in water or a -1.2 MPa solution until different seed water contents were reached.

\begin{tabular}{|c|c|c|}
\hline \multirow{3}{*}{ Seed water content $(\%)$} & \multicolumn{2}{|c|}{ Immersion medium } \\
\hline & Water & -1.2 MPa Solution \\
\hline & \multicolumn{2}{|c|}{ Germination $(\%)$} \\
\hline 10 (initial) & $67 \pm 2.24 \mathrm{Aa}$ & $67 \pm 2.24 \mathrm{Aa}$ \\
\hline 15 & $62 \pm 2.83 \mathrm{Ab}$ & $65 \pm 2.24 \mathrm{Aa}$ \\
\hline 20 & $64 \pm 2.19 \mathrm{Aab}$ & $44 \pm 4.38 \mathrm{Bb}$ \\
\hline 35 & $42 \pm 2.19 \mathrm{Ac}$ & $15 \pm 1.67 \mathrm{Bc}$ \\
\hline \multirow[t]{2}{*}{ C.V. $(\%)$} & \multicolumn{2}{|c|}{4.89} \\
\hline & \multicolumn{2}{|c|}{ Average germination time (days) } \\
\hline 10 (initial) & $24 \pm 2.64 \mathrm{Ab}$ & $24 \pm 2.64 \mathrm{Ac}$ \\
\hline 15 & $25 \pm 2.19 \mathrm{Ab}$ & $25 \pm 1.37 \mathrm{Ac}$ \\
\hline 20 & $30 \pm 1.35 \mathrm{Aa}$ & $31 \pm 1.60 \mathrm{Ab}$ \\
\hline 35 & $30 \pm 1.43 \mathrm{Ba}$ & $45 \pm 0.84 \mathrm{Aa}$ \\
\hline C.V. $(\%)$ & \multicolumn{2}{|c|}{6.34} \\
\hline & \multicolumn{2}{|c|}{ Speed of germination index } \\
\hline 10 (initial) & $1.54 \pm 0.04 \mathrm{Aa}$ & $1.54 \pm 0.04 \mathrm{Aa}$ \\
\hline 15 & $1.69 \pm 0.22 \mathrm{Aa}$ & $1.41 \pm 0.06 \mathrm{Ba}$ \\
\hline 20 & $1.18 \pm 0.03 \mathrm{Ab}$ & $0.76 \pm 0.10 \mathrm{Bb}$ \\
\hline 35 & $0.74 \pm 0.05 \mathrm{Ac}$ & $0.17 \pm 0.02 \mathrm{Bc}$ \\
\hline C.V. $(\%)$ & & \\
\hline
\end{tabular}
Averages followed by the same upper-case letter within a line and the same lower-case letter within a column are not significantly different according to Tukey's test at $p<0.05$ ( \pm standard deviation). 


\section{Figure captions}

Figure 1. Ultrastructure of Annona emarginata (Schltdl.) H. Rainer embryonic axes of seeds before imbibition (A-C), after 122 hours (D-F) and 317 hours of immersion (G-I). (A) Overview of axis cells before imbibition and (D) after 122 hours with thick cell walls, (G) and after 317 hours with non-uniform cell walls. Arrow indicates cell wall. (B, C) Ultrastructure before imbibition, nucleus (nu), mitochondria (mi) with cristae and distinguishable internal and external membranes, numerous small lipid bodies (lb), starch grains (st), and storage vacuoles containing sugars (va). (E, F) Ultrastructural changes after 122 hours of immersion including more abundant mitochondria, with an irregular shape, poorly developed cristae, and limited distinction between the internal and external membranes than unimbibed cells. (H, I) Ultrastructural changes in cell organelles after 317 hours of immersion including non-uniform cell walls (cw) with signs of degradation and disruption of sugar-containing storage vacuoles, more abundant mitochondria (mi), with an irregular shape, poorly developed cristae, and limited distinction between the internal and external membranes than unimbibed cells. Scale bars are $5 \mu \mathrm{m}(\mathrm{A}, \mathrm{D}) ; 0.6 \mu \mathrm{m}(\mathrm{B}) ; 0.5 \mu \mathrm{m}(\mathrm{C}, \mathrm{F}) ; 2 \mu \mathrm{m}(\mathrm{G}, \mathrm{I}) ; 500 \mathrm{~nm}(\mathrm{E}, \mathrm{H})$. 

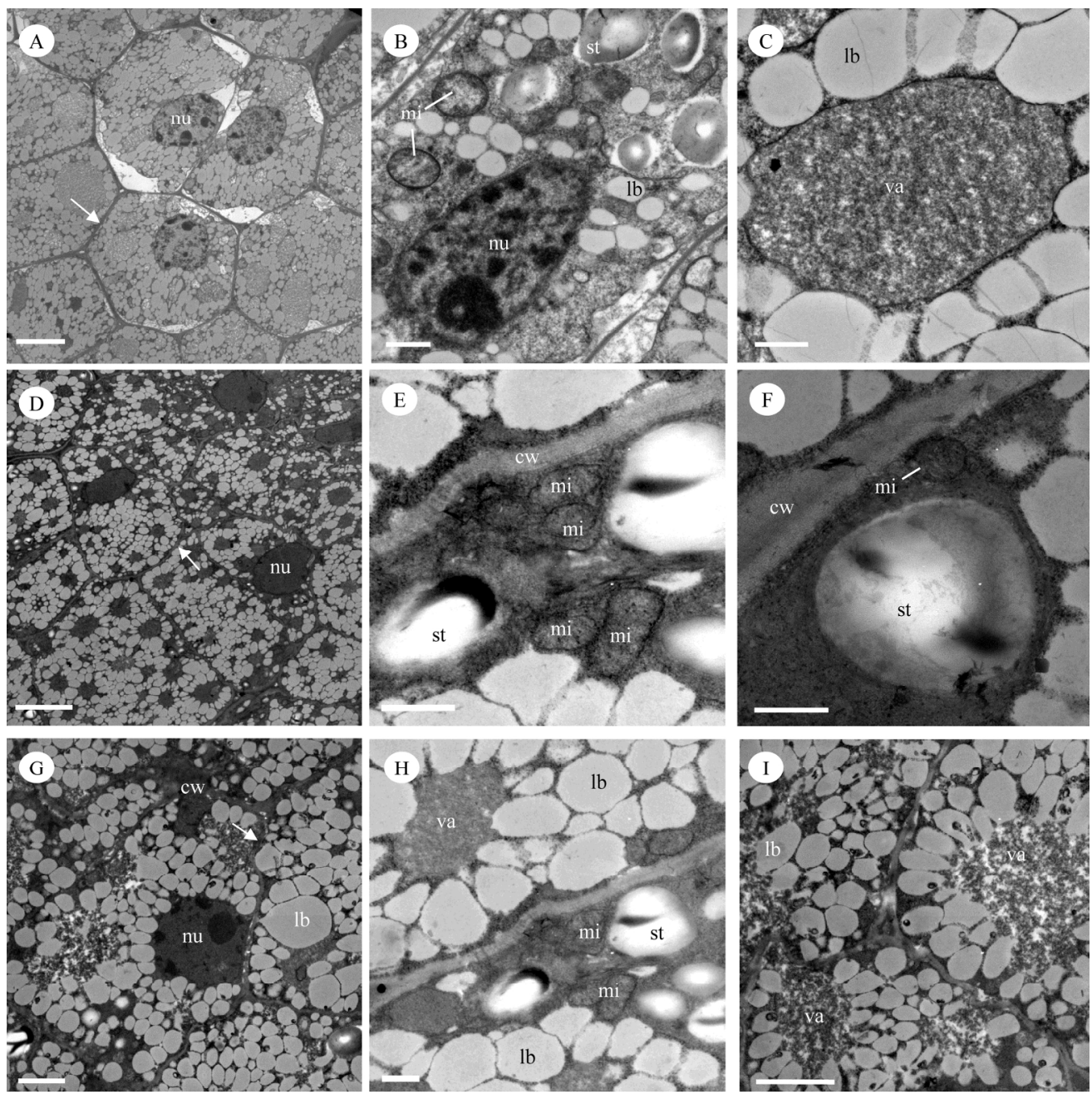

Figure 1. Ultrastructure of Annona emarginata (Schltdl.) H. Rainer embryonic axes of seeds before imbibition (A-C), after 122 hours (D-F) and 317 hours of immersion (G-I). (A) Overview of axis cells before imbibition and (D) after 122 hours with thick cell walls, (G) and after 317 hours with non-uniform cell walls. Arrow indicates cell wall. $(B, C)$ Ultrastructure before imbibition, nucleus (nu), mitochondria (mi) with cristae and distinguishable internal and external membranes, numerous small lipid bodies (Ib), starch grains (st), and storage vacuoles containing sugars (va). (E, F) Ultrastructural changes after 122 hours of immersion including more abundant mitochondria, with an irregular shape, poorly developed cristae, and limited distinction between the internal and external membranes than unimbibed cells. $(\mathrm{H}, \mathrm{I})$ Ultrastructural changes in cell organelles after 317 hours of immersion including non-uniform cell walls (cw) with signs of degradation and disruption of sugar-containing storage vacuoles, more abundant mitochondria (mi), with an irregular shape, poorly developed cristae, and limited distinction between the internal and external membranes than unimbibed cells. Scale bars are $5 \mu \mathrm{m}(\mathrm{A}, \mathrm{D}) ; 0.6 \mu \mathrm{m}(\mathrm{B}) ; 0.5 \mu \mathrm{m}(\mathrm{C}, \mathrm{F}) ; 2 \mu \mathrm{m}(\mathrm{G}, \mathrm{I}) ; 500$ $\mathrm{nm}(\mathrm{E}, \mathrm{H})$.

$182 \times 182 \mathrm{~mm}(300 \times 300 \mathrm{DPI})$ 